\title{
CAUSES AND CONSEQUENCES OF ECONOMIC CRIMES LINKAGE IN THE CONTEMPORARY REALITIES OF INTEGRATION PROCESSES
}

\author{
Rostyslav Lemekha', Bogdan Schur²
}

\begin{abstract}
The economically and socially advanced countries of the world have encountered a number of issues that are not new and examples of the systematic recurrence of which are known in Europe, Asia, America, Africa. The spread of infectious diseases and the fight against their worst consequences have become relevant to different countries at least every 50 years. Such recurrence, and therefore high probability and expectation, should be taken into account in the National Security Strategies and, rather, resources should be accumulated quickly to minimize the adverse effects on societies and the world at large. Nonetheless, the first quarter of 2020 has been extremely difficult for countries that, with their vast array of new technologies, have been unable to navigate the dangers of COVID-19 coronavirus disease or take precautionary measures without undue panic quickly. In addition to these generally strategic ones, a number of other problems have become apparent. These include the following, which relate to counter crimes that are committed in the economy and keep the gaps in policy approaches to identify the causes and effects of all other related aspects of society. Therefore, the overriding task of international organizations, national governmental and non-governmental organizations are the development of concerted recommendations for the formulation and maintenance of systematic development of national and world security strategies. The component of economic security is particularly important, which is emphasized in virtually every speech by statesmen of countries suffering from the spread of COVID-19 coronavirus disease. There is no doubt that the protection of the interests of public and private persons, producers, compliance with the requirements of ratified international pacts, other documents at all levels of the government of the state for the awareness of the cause-and-effect relations of economic crimes (to which all members of the corporation should apply) remains paramount, which is unfortunately very low in Ukraine today. Methodology. The stated purpose of this article is primarily related to the use of the cognitive potential of a number of philosophical, general scientific and special methods. The dialectical methods of analysis and synthesis, the comparative-legal method have become the methods of research taking into account the desire to determine the directions of development of foreign and national scientific opinion on the subject of the publication, they have allowed to distinguish perspective measures to counteract these offenses, taking into account the experience of the highly developed EU countries. Methods of grammatical examination and interpretation of legal norms have helped to identify the gaps in the legislation governing the grounds and the procedure for bringing to justice the perpetrators of them, to develop proposals for its improvement. Practical importance. Establishing causality of crimes in the sphere of economy, shadowing the economy, which occurs in particular by committing corruption crimes, will help to identify systematic measures and effective instruments (including legal norms) aimed at preventing their spread and eliminating the negative impact of social institutions, relationships, which are not even perceived by most members of society today. Awareness of the cause and effect of relationships of crimes in the field of economics will enable theoretical and practical support for the prevention of their negative consequences by using adequate legal and other mechanisms. An attempt to solve such a problem is presented in this study.
\end{abstract}

Key words: causation, property damage, criminal outcomes, crimes in the economic sphere, restitution, socially dangerous consequences, the purpose of criminal penalties, corruption crimes.

JEL Classification: P11, K14, H51

\footnotetext{
Corresponding author:

${ }^{1}$ Danylo Halytsky Lviv National Medical University, Ukraine.

E-mail: roslemekha@gmail.com

${ }^{2}$ Lviv University of Trade and Economics, Ukraine.

E-mail: bogdanshchur1965@ukr.net
} 


\section{Introduction}

Analysis of the legal protection of public relations in the sphere of economy allows to establish that it is mainly provided by means of criminal law, by establishing criminal liability for socially dangerous acts, the lists of which differ depending on the legal traditions of a particular crane. However, such remedies are usually not limited but form an integrated approach using the opportunities of other fields of law (Tylchyk, et al., 2018).

For example, in the UK, the activity of the financial sector is governed by two sets of rules: civil and criminal law. In this approach, despite the preference for civil law in quantitative terms, parity remains between the interests of business and the interests of the state, that is, business interests are "protected" by civil law, and the interests of the state by criminal law. The differentiation of criminal liability is due to the use of qualifying signs of crime both horizontally (within one part of the article) and vertically (for example, when passing qualifying features from serious to especially serious). In The United States, among the crimes that are referred to as economic crimes in the Post-Soviet Codes, there are not only common criminal rules that "cover" virtually all economic processes, but also stand out rules that provide for liability for the most dangerous and sufficiently pervasive crimes. in particular spheres or sectors of economic activity (Streltsov, 2014).

In contrast to the above example, Ukraine and other countries of the post-Soviet space are dominated by the approach to defining crimes of any kind exclusively by criminal law (the Criminal Code). However, many of the normative acts that it refers to, including administrative law, contain prescriptions for the types of administrative offenses and penalties for committing them. In domestic legal doctrines, sometimes it is argued that the basis of such graduation of types of legal liability is the degree of social danger, harmfulness of the offense, and therefore many crime and qualifying traits are such that characterize precisely the qualitative and quantitative characteristics of consequences (harm). There should be separately mentioned the property (as an example, causing property damage to the Ministry of Defense of Ukraine in connection with the misuse of budget funds in the process of inflating contract prices for housing construction for servicemen to obtain military equipment, weapons, equipment, clothing, medicines, food, etc.). Such damages are in turn divided into direct pecuniary and indirect (lost profits and criminal justice costs).

According to scientist Tylchyk O. (2018), the costs of criminal justice make up about $2 \%$ of Ukraine's gross domestic product, and it is difficult to calculate the lost profits from economic crime, as well as the shadowing of the economy.

It is also worth acknowledging the existence of damage that can be conditionally attributed to material, although the deduction of its specific results is not possible: reducing the attractiveness of investment and the level of protection of economic relations, reducing the competitiveness of domestic producers, monopolization of the market, reducing the activity of market relations, suppression of such activity, etc.

In the last decade, the attention of the European Community has been drawn to the development of means of combating the legalization (laundering) of proceeds of crime (Tylchyk, 2018). This, on the one hand, is an independent type of crime; on the other hand, it is usually the result: the consequences of individual crimes, many of which are committed in the economic sphere. As a result of the actions of the subjects determined by the Criminal Law, such results, namely the proceeds of crime are the subject of a new crime. Their quantitative characteristics are now counted, however, according to scientists, they are significantly low due to the high latency of crimes in the field of economy.

In 2017, the officially established amount of proceeds of crime (under indictments) amounted to almost 6.5 billion UAH, the amount of unpaid taxes, fees, and other mandatory payments - 3.3 billion $\mathrm{UAH}$, the amount of hidden profit - almost 5 million UAH, and the cost of counterfeit and substandard goods - over 7 million UAH. Given that the amount of registered economic crimes is about $10 \%$ of the actual number of economic crimes, the direct material damage from economic crime can be much higher (only report criminal offenses for January - December 2017). Therefore, research into the cause and effect relationships of crimes in the field of economy is a priority area of the humanities.

\section{Definition of the concept of causation in crimes in the sphere of economy}

Theories of causation are associated with the doctrine of "condition" (siconditio sine gua non), or the "equivalent causation" of Thomas Hobbes. The object of this theory was the behavior of a particular person in the aspect of answering the question of its relevance to the cause. The reason is such a condition, the mental exclusion of which excludes the possibility of consequences, if the consequence occurred despite the elimination of the condition, then the reason is defined incorrectly (with all the conditions, the possible reasons are legally equal. In addition, the theory of the necessary condition, formulated by Ortman, Birkmeister, Binding, recognizes the cause of any condition in the absence of which it is impossible to achieve the result. Unlike the previous theory, the conditions are recognized as non-equilibrium, the decisive, the most effective conditions are distinguished. Under the theory, a condition determines the cause of consequence when it increases the probability and possibility of such an outcome, and if it (the result) is a typical result of the condition that is the cause. If the results are not typical conditions, there is no causal relationship. The criterion 
for determining the typicality: consciousness authorized officer, consciousness offender - unauthorized persons. Modern theories of causality, in particular the AngloAmerican system of law, determine that harm is an inevitable consequence of a breach of a duty to comply with legal requirements. The jurisprudence of Germany, Austria, and Switzerland determines that a legally valid causal link exists if the objective achieved by the subject is the result of his/her behavior and corresponds to the real state of things (Tanriveriev). Any activity of a person causes changes in the environment. Due to the axiomatic nature of the above thesis, it does not raise any objection and assertion that crimes in the sphere of economy, as a type of behavior, lead to negative changes of objective reality in the specified and tangible spheres.

In the aspect of criminallaw, not only the consequences of the crime but also the criminal consequences or results are defined as a link between the criminal act (inaction) and the object of the criminal offense as material or non-pecuniary damage, defined by the criminal law norm, the object of the encroachment. It should be agreed with scientists who emphasize that the process of causation is not a linear but structurally complex process of interaction of constituent systemic causes, which mediates a successfully dangerous result (Soktoyev, 2014).

The reasons for the steady increase in crimes in the sphere of the economy are caused, first of all, by the global socio-economic and political crisis in the country, which, against the backdrop of the spread of the pandemic, is gaining ground. Therefore, the organization of an effective system for combating economic crime is possible only on the basis of the unity of general social, socio-criminological and legal measures, including criminal law.

In the structure of economic crime, the size of the damage caused is dominated by crimes in the banking sector, in the sphere of international economic relations. Official statistics on the dynamics of economic crime are not objective and incomplete.

Given these circumstances, it is possible to agree with the findings that general measures - social card - become crucial for the prevention of criminal behavior. They should aim at a) a clear definition of the functions of the state in regulating economic relations; b) the formation of its economic and legal policy; c) distribution of powers between central and local authorities in regulating economic processes; d) creation of appropriate conditions for the proper legal behavior of economic operators; e) ensuring equal legal protection of the public and private sectors of the economy; f) creation of such market infrastructure that would provide equal opportunities for realizing the creative potential of various business entities; i) establishing democratic principles of control over the activity of business structures, etc. (Olashin, 2015).

\section{Correlation of the consequences of the crimes in the sphere of economy and legal responsibility}

As a component of causation, the consequences of committing crimes in the economic sphere can be characterized as a separate social and legal phenomenon, in which the signs, properties of the crime, the nature and features of the object of crime are repeated: the normatively determined and protected procedure of economic activity. The most detailed causation analysis is offered in the doctrine of criminal law. However, as it has been repeatedly noted by researchers, the issue of revising most of the provisions to date is developed with a view to updating the concept of counteracting the shadow economy and determining the place of legal liability for offenses, including crimes, in the economic sphere among the means of counteracting it.

Analyzing the system and types of punishments that are imposed for such crimes, scientists indicate that the main goals that the legislator pursues in the countries of the Anglo-Saxon legal family are: the punishment of the offender; if not in the full correction of the criminals, then at least in "warning" him/her in committing new crimes; in cases of necessity, compensation for harm to the victims of the crime; reducing crime; protection of society and others (Streltsov, 2014). At the same time, compensation for the victims of crimes in this category, as evidenced by the statistical reports on the results of the activities of law enforcement agencies for the detection of these crimes, is not their priority. In trying to remedy such provisions, lawmakers have recently been decriminalizing criminal acts, which in turn leads to the formation of impunity in the public consciousness and leads to an increase in the amount and magnitude of the harm caused by such offenses. The need to establish such causal relationships is obvious.

However, it should be borne in mind that sanctions of criminal law differ substantially from those types of liability, which are in the regulatory fields of law and have a compensatory orientation there. As the scientists point out, each branch of law must perform one basic function, which directly follows from the main task before it. Such a basic general function, which is specific to a particular field of law, is determined by the basic number, orientation, and content of the legal norms inherent in a particular branch of law. Therefore, a crucial function of criminal law is a protective function, since the vast majority of the basic rules of this area of law are aimed at protecting values, interests, and benefits from prohibited acts (Streltsov, 2014).

The UN Declaration of Basic Principles of Justice for Victims of Crime and Abuse of Power (1985) recommends that States include restitution as a punishment in their laws. Criminal restitution has also been addressed in the European Convention on the Compensation of Victims of Violent Crime Council (1983), the CoE Recommendations on the Status of 
Victims within the framework of Criminal Law and Criminal Procedure, and on Criminal Justice in Europe (Changing Europe, 1985). The second of these acts, in particular, states that: compensation to the victim may be imposed in the form of a criminal sanction or in the form of a measure instead of the sanction, or in addition to it; if compensation is intended as a criminal sanction, it must be enforced in a similar manner to the enforcement of penalties and take precedence over other financial penalties applicable to the offender.

The current situation in Ukraine in connection with the introduction of a number of measures aimed at curbing the negative effects of the spread of COVID-19 coronavirus disease, especially regarding the significant restriction of the individual's rights to carry out economic activities, is quite indicative of the state and prospects of development legal responsibility, including for crimes in the sphere of economy. The enforcement of sanctions for violations of the established legal regime, which predominantly involves substantial penalties, has led to a significant negative reaction of the majority of the population. Particularly noteworthy is the significant discrepancy in the number of penalties for such violations compared to even the average wage at the tap. A large-scale practice of appealing against decisions in cases of relevant offenses is predicted, in case of violation by the authorized subjects of proceedings for their commission. The non-proportionality of penalties for these offenses for other crimes prompts another rethinking of the provisions of the doctrine of criminal law in this area. Considering that in criminal law compensation for harm caused by crime is considered in two respects - as voluntary and as compulsory, important attempts to form the basis of activation not only the latter, as related and different legal consequences of such compensation.

\section{References:}

Bielai, S., Morozov, I., \& Tylchyk, V. (2018). The innovative approach to the crisis situations monitoring of the social and economic origin that endanger the security of Ukraine. Baltic Journal of Economic Studies, vol. 4, no. 3, pp. 15-21. doi: 10.30525/2256-0742/2018-4-3-15-21

Deklaratsiya osnovnykh pryntsypiv pravosuddya dlya zhertv zlochyniv ta zlovzhyvannya vladoyu [Declaration of the basic principles of justice for victims of crime and abuse of power]. Retrieved from: https://zakon.rada.gov.ua/ laws/show/995_114 (accessed March 29, 2020). (in Ukrainian)

Jankovska, L., Tylchyk, V., \& Khomyshyn, I. (2018). National economic security: an economic and legal framework for ensuring in the conditions of the European integration. Baltic Journal of Economic Studies, vol. 4, no. 1, pp. 350-357. doi: 10.30525/2256-0742/2018-4-1-350-357

Olashin, M. (2015). Ekonomichna zlochynnist' prychyny poshyrennya i shlyakhy podolannya [Economic crime causes of spread and ways of overcoming]. Yevropeys'ki perspektyvy [European perspectives], no 7, pp. 102-105. (in Ukrainian)

Pashko, P., Tylchyk, O., \& Kotukha, O. (2018). Ontology of scientific cognition of shadow economy and economic shading. Baltic Journal of Economic Studies, vol. 4, no 2, pp. 151-158. doi: 10.30525/2256-0742/2018-4-2-151-158 Rekomendatsiya R (85) 11 Komitetu ministriv derzhavam-chlenam stosovno polozhennya poterpiloho v mezhakh kryminal'noho prava ta kryminal'noho protsesu [Recommendation R (85) 11 of the Committee of Ministers to the Member States on the situation of victims within the framework of criminal law and criminal procedure]. Retrieved from: https://zakon.rada.gov.ua/laws/show/994_127 (accessed March 29, 2020). (in Ukrainian)

Soktoev, Z. B. (2014). Prichinnost' v ugolovnom prave: teoreticheskiye i prikladnyye problem [Causality in criminal law: theoretical and applied problems]. Dis. ... Dr. Jur. Sciences. Moscow. (in Russian)

Streltsov, E. (2014). Vidpovidal'nist' za ekonomichni zlochyny v kranakh anhlo-saksons'koyi pravovoyi rodyny [Responsibility for economic crimes in the cranes of the Anglo-Saxon legal family]. Scientific Bulletin of the International Humanities University, vol. 2, no 11, pp. 66-99.

Tanriverdiyev, A. (2008). Problemy prichinnoy svyazi v grazhdanskom prave [Problems of causal connection in civil law]. Lawyer, no 9, pp. 45-49. (in Russian)

Tylchyk, O., Dragan, O., \& Nazymko, O. (2018). Establishing the ratio of concepts of counteraction to legalization (laundering) of illegally-obtained income and counteraction to the shadow economy: the importance of determining performance indicators of the European integration processes. Baltic Journal of Economic Studies, vol. 4, no 4, pp. 341-346. doi: 10.30525/2256-0742/2018-4-4-341-345

Tylchyk, O. Riabchenko, Y., \& Popivniak, O. (2018). Management (administrative) activity of the controlling authorities in the area of taxation: essence and types. Baltic Journal of Economic Studies, vol. 4, no 5, pp. 343-351. doi: 10.30525/2256-0742/2018-4-5-343-351

Tylchyk, O., Pluhatar, T., \& Kotukha, O. (2018). Determinants of shadowing of the economy: the genesis of economic and legal doctrines. Baltic Journal of Economic Studies, vol. 4, no. 3, pp. 302-308. doi: 10.30525/22560742/2018-4-3-302-308

Yedynyy zvit pro kryminal'ni pravoporushennya za sichen' - hruden' (2017). [Unified Criminal Report for JanuaryDecember 2017]. Heneral'na prokuratura Ukrayiny [The Prosecutor General's Office of Ukraine]. Retrieved from: https://www.gp.gov.ua/en/stst2011.html?dir_id=113281\&libid=100820\&c=edit\&_c=fo (accessed March 18, 2020). (in Ukrainian)

Yevropeys'ka konventsiya po vidshkoduvannyu shkody zhertvam nasyl'nyts'kykh zlochyniv [European Convention on Compensation for Victims of Violent Crime]. Retrieved from: https://zakon.rada.gov.ua/laws/show/994_319 (accessed March 29, 2020). (in Ukrainian) 